\title{
Perceived Social Support dan Psychological Distress Pada Penderita Penyakit Kanker
}

\author{
Windi Maryanti, Ika Herani \\ Fakultas IImu Sosial dan IImu Politik Universitas Brawijaya \\ email: windimaryanti@student.ub.ac.id
}

\begin{abstract}
Abstrak
Artikel INFO

Diterima:06 Feb 2020

Direvisi :14 Mei 2020

Disetujui:11 Juni 2020

DOI:

http://dx.doi.org/10.24014/ jp. 1442.9155

Psychological distress merupakan keadaan penderitaan emosional yang ditandai oleh gejala depresi dan kecemasan. Gejala depresi dan kecemasan sering dialami oleh pasien kanker berkaitan dengan kondisi penyakit dan proses pengobatannya. Salah satu sumber daya koping yang sering dianggap dapat membantu penurunan gejala depresi dan kecemasan pada individu adalah dukungan sosial. Penelitian ini bertujuan untuk mengetahui hubungan antara perceived social support dengan psychological distress pada penderita penyakit kanker. Metode yang digunakan adalah kuantitatif dengan desain korelasional. Teknik pengambilan sampel yang digunakan adalah purposive sampling dengan subyek penelitian yaitu pasien dengan diagnosis kanker dan masih menjalani perawatan pengobatan atau pemulihan di rumah sakit. Jumlah subjek yang diperoleh sebanyak 145 pasien. Instrumen yang digunakan dalam penelitian ini adalah skala Multidimentional Scale of Perceived Social Support (MSPSS), dan Hopkins Symptom Checklist - 25 (HSCL 25). Data yang diperoleh dianalisis menggunakan Pearson product moment. Hasil analisis menunjukkan bahwa tidak terdapat hubungan yang signifikan antara perceived social support dengan psychological distress pada penderita penyakit kanker.
\end{abstract}

Kata kunci: Kanker,perceived social support, psychological distress

\section{Perceived Social Support and Psychological Distress in Cancer Patients}

\begin{abstract}
Psychological distress is a state of emotional distress characterized by symptoms of depression and anxiety. Symptoms of depression and anxiety are often experienced by cancer patients related to the condition of the disease and the treatment process. One of the coping resources that is often considered to help reduce symptoms of depression and anxiety is social support. This study aims to determine the relationship between perceived social support and psychological distress in cancer sufferers. The method used is quantitative with a correlational design. The sampling technique used was purposive sampling. Research subjects are patients with a cancer diagnosis and still undergoing treatment or recovery treatment in the hospital. The number of subjects obtained was 145 patients. The instruments used in this study were the Multidimentional Scale of Perceived Social Support (MSPSS), and the Hopkins Symptom Checklist 25 (HSCL 25). The data obtained were analyzed using Pearson product moment. The analysis showed that there was no significant relationship between perceived social support and psychological distress in cancer patients.
\end{abstract}

Keywords: Cancer, perceived social support, psychological distress

\section{Pendahuluan}

Penyakit kronis mengacu pada gangguan tubuh atau kesehatan jangka panjang, yang berkaitan dengan penyakit menular atau tidak menular, sindrom, dan disorder. Hal ini merupakan pengalaman yang mengganggu, tidak menyenangkan, dan tidak diinginkan secara fisik maupun mental (Martin, 2007).

Pernyakit kronis terbagi menjadi dua, yaitu penyakit menular (communicable) dan penyakit tidak menular (non-communicable). Berdasarkan data Riskesdas tahun 2018, prevalensi penyakit tidak menular di Indonesia mengalami peningkatan dibandingan dengan Riskesdas tahun 2013, salah satunya 
adalah penyakit kanker. Prevalensi kanker di Indonesia meningkat dari 1.4 per 1000 penduduk di tahun 2013 menjadi 1,79 per 1000 penduduk pada tahun 2018 . Hal tersebut menyebabkan Indonesia berada pada urutan 8 di Asia Tenggara dengan angka kejadian penyakit kanker tertinggi (136.2/100.000 penduduk) (Kemenkes, 2019). Kenaikan prevalensi penyakit kanker berkaitan dengan pola hidup seperti aktivitas fisik, kurangnya konsumsi buah dan sayur, konsumsi minuman alkohol, dan merokok (Riskesdas, 2018). Penyakit kanker ini timbul akibat pertumbuhan tidak normal sel jaringan tubuh yang berubah menjadi sel kanker (Kemenkes, 2015). Selain dapat menyebabkan kematian, penyakit kronis seperti kanker juga memberikan dampak dan keterbatasan bagi penderitanya.

Penderita penyakit kronis lebih memiliki peluang untuk mengalami ketergantungan terhadap bantuan dari orang lain. Kondisi ini mengindikasikan ketidakmaksimalan pengidap penyakit kronis dalam menjalani aktivitasnya (Hamzah, Dewi, \& Suparno, 2014). Keterbatasan dan pelemahan kondisi tubuh (kecacatan, nyeri, perubahan penampilan) memiliki konsekuensi umum yang menghasilkan stres (Verhaak, Heijmans, Peters, \& Rijk, 2005). Penelitian Widagdo dan Besral (2013) menunjukkan bahwa terdapat hubungan penyakit kronis (kanker, tuberculosis paru, hepatitis, jantung, diabetes mellitus, dan stroke) dan faktor risiko lain dengan gangguan mental emosional, apabila individu menderita penyakit kronis, maka semakin besar juga risiko individu tersebut untuk mengalami gangguan mental emosional. Widagdo dan Besral (2013) juga menambahkan bahwa tingginya tingkat risiko gangguan mental emosional pada individu yang menderita penyakit kronis, kemungkinan terjadi karena individu merasa kekuatan fisiknya terancam sebagai akibat dari gangguan atau keterbatasan fisiologis sehingga fungsi sosialnya juga mengalami penurunan.

Selain mengalami keterbatasan fisiologis dan penurunan fungsi sosial, penderita penyakit kronis khususnya kanker, juga dapat mengalami permasalahan yang berkaitan dengan finansial. Pengobatan kanker yang relatif mahal dan berlangsung lama membutuhkan banyak biaya, yang secara langsung dapat mengubah ekonomi keluarga penderita kanker serta menimbulkan kecemasan tersendiri bagi penderita kanker (Prastiwi, 2012). Pada tingkat keterbatasan fungsional yang menimbulkan dampak sosial, relasional atau material tersebut, pada akhirnya dapat meyebabkan penderita kanker mengalami psychological distress (Verhaak et al, 2005).

Psychological distress merupakan keadaan penderitaan emosional yang ditandai dengan gejala depresi (misal; kehilangan minat, kesedihan, keputusasaan) dan kecemasan (misal; gelisah, perasaan tegang) (Mirowsky \& Ross, 2003). Tingkat psychological distress dapat disebabkan oleh dua pengaruh, yaitu: intrapersonal, seperti sifat-sifat kepribadian dan pengaruh situasional, seperti peristiwa dalam hidup (Matthews, 2000). Faktor situasional dari lingkungan yang mendorong psychological distress misalnya peristiwa traumatis, faktor fisik, faktor sosial, dan kesehatan yang buruk (Matthews, 2000). Psychological distress berhubungan dengan penyakit kronis sehingga penting untuk fokus pada kebutuhan sosio-emosional pasien yang kronis karena mereka sudah menghadapi penderitaan yang sangat buruk (Sohail, Yasin, \& Ahmad, 2017).

Menurut Ng, et al., (2015) penderita penyakit kanker diketahui menderita tingkat psychological distress yang tinggi sejak awal diagnosa penyakit. Hal ini terkait dengan ketakutan dan ketidakpastian terhadap penyakit dan perawatannya. Pasien kanker juga mengalami perjalanan kecemasan yang fluktuatif selama fase diagnosis dan pengobatan. Selain itu, dari saat diagnosis, pasien kanker mengalami berbagai jenis tekanan mental dan adaptasi untuk proses pengobatan kanker termasuk penyelidikan penyakit, menunggu hasil, perencanaan operasi, kemoterapi, terapi hormon, radioterapi dan pemulihan $(\mathrm{Ng}$, et al., 2015). Hasil penelitian Widiyono (2017) menunjukkan bahwa sebanyak $25,71 \%$ pasien kanker mengalami depresi ringan, 
$45,71 \%$ mengalami depresi sedang; dan $28,58 \%$ mengalami depresi berat, hal ini berkaitan dengan kondisi sakit yang mereka alami sehingga menyebabkan mereka mengalami kecemasan dan depresi. Hamer, Chida, dan Molloy (2009) menyebutkan bahwa psychological distress yang ditandai dengan kecemasan dan depresi terkait dengan peningkatan mortalitas pada individu yang memiliki riwayat kanker, psychological distress juga menjadi prediktor kematian pasien kanker, terutama pada kanker paruparu. Oleh karena itu, pasien penderita kanker memerlukan bantuan dukungan sosial untuk tetap berpikir positif akan keadaan dirinya sehingga mampu menurunkan kecemasan, depresi dan ketidakberdayaan (Nurjanah \& Fourianalistyawati, 2013).

Menurut Madani, Pourmemari, Moghimi dan Rasvand (2018) Ketersediaan dukungan sosial dianggap sebagai sumber daya koping yang signifikan yang dapat membantu pasien bertahan hidup dengan kanker, serta mengatasi banyak tekanan yang datang dengan penyakit dan perawatannya. Selain itu, dukungan sosial juga dapat mengurangi ketegangan, meningkatkan tingkat kelangsungan hidup, meningkatkan status kesehatan, dan meningkatkan kualitas hidup pasien (Madani, et al., 2018). Dukungan sosial dapat dikarakteristikkan sebagai sumber daya koping yang tepat untuk mengurangi efek psikologis negatif dari stresor yang ada dan memiliki efek penting pada prognosis penyakit kronis (Gunduz, Unsen, \& Atar, 2018).

Terdapat dua jenis subkelompok dukungan sosial yaitu perceived social support dan received social support. Received social support adalah jumlah aktual dukungan yang diterima individu ketika menghadapi stres, sementara perceived social support adalah pemikiran individu bahwa dukungan tersebut tersedia jika diperlukan. Dari dua konstruksi dukungan sosial ini, hanya perceived social support yang dianggap secara konsisten terkait dengan kesehatan (Haber, Cohen, \& Lucas, 2007).

Menurut Rodriguez dan Cohen (dalam Lourel, 2013) perceived social support membantu untuk meningkatkan persepsi individu tentang kemampuannya dalam mengatasi peristiwa yang menimbulkan stres. Perceived social support dapat memainkan peran antara reaksi stres dan stresor serta proses patologi (psikologis atau fisik) dengan mengurangi atau menghilangkan reaksi stres serta memperkuat upaya coping. Hal ini sejalan dengan pendapat Roohafza, Afshar, Keshteli dan Narg (2014) yang menyatakan bahwa perceived social support memiliki peran protektif untuk masalah psikologis (depresi dan kecemasan) dengan mengurangi persepsi akan situasi yang mengancam dan meningkatkan keyakinan bahwa sumber dukungan sosial tersedia.

Sumber percieved social support ini dapat berasal dari keluarga, teman, dan orang yang dianggap spesial/significant others (Zimet, Dahlem, Zimet , \& Farl, 1988). Kekuatan dukungan sosial yang berasal dari relasi yang terdekat merupakan salah satu proses psikologis yang dapat menjaga perilaku sehat dalam diri seseorang. Dukungan yang bersumber dari keluarga (misal: pasangan, anak, orangtua, dan saudara) juga dapat mengurangi kecemasan pasien terhadap perasaan kehilangan atau ditinggalkan dan ditelantarkan oleh anggota keluarga (Nurjanah \& Fourianalistyawati, 2013). Dukungan bagi pasien yang bersumber dari lingkungan sosial, terutama keluarga, akan membuat pasien merasa diperhatikan dan tidak sendirian dalam menjalani kemoterapi sehingga akan menjadi kekuatan bagi pasien dalam menjalani rangkaian proses kemoterapi (Kirana, 2017).

Penelitian pada pasien penyakit kronis seperti kanker, hepatitis, penyakit jantung koroner dan diabetes oleh Khawar, Aslam, dan Aamir (2013) di Pakistan menunjukkan bahwa perceived social support berhubungan signifikan kearah negatif dengan psychological distress maupun physical distress yang dihubungkan dengan kecemasan akan kematian dan keyakinan tentang apa yang akan terjadi setelah kematian (Khawar, Aslam, \& Aamir, 2013). Hal tersebut sejalan dengan penelitian Madani et al (2018) yang menyatakan bahwa percieved social support yang tinggi berhubungan dengan 
tingginya harapan hidup pasien kanker, dimana harapan hidup yang tinggi tersebut dapat meningkatkan status psikologis pasien kanker.

Pasien dengan percieved social support memiliki kualitas hidup yang lebih tinggi dan psychological distress yang lebih rendah (Nevo, et al., 2018). Hal tersebut juga sejalan dengan penelitian Yoo, et al (2017) yang menunjukkan bahwa perceived social support yang rendah berhubungan dengan gejala depresi yang lebih tinggi dan kualitas hidup yang rendah pada pasien kanker maupun pada populasi secara umum. Penelitian Pałkowska, et al., (2016) menyatakan bahwa dukungan sosial merupakan sumber daya psikososial penting yang memberikan pasien bantuan psikologis, informasi, atau saran dimana berperan membantu pasien menemukan solusi dan memfasilitasi pasien. Dukungan sosial juga dapat membantu pasien memuaskan kebutuhan untuk dihibur dan didengar atau memperbaiki status keuangannya. Sehingga, ketersediaan dukungan sosial yang dipersepsikan oleh pasien selama periode sakit berhubungan positif dengan penilaian pasien terhadap penyakitnya, pasien yang menilai penyakitnya secara positif terkait dengan hasil adaptasi yang lebih baik, seperti kualitas dan penerimaan hidup yang lebih tinggi, serta gejala depresi yang lebih rendah (Pałkowska, etal., 2016). Berdasarkan pemaparan tersebut peneliti ingin mengetahui apakah terdapat hubungan yang signifikan antara perceived social support dengan psychological distress pada penderita penyakit kanker.

\section{Metode}

Desain penelitian dalam penelitian ini menggunakan metode kuantitatif dengan pendekatan korelasional karena bertujuan untuk mengetahui hubungan antara variabel perceived social support dengan psychological distress pada penderita penyakit kanker.

\section{Subjek}

Subyek penelitian ini adalah pasien dengan diagnosis kanker dan masih menjalani perawatan pengobatan atau pemulihan di rumah sakit. Teknik pengambilan sampel yang digunakan adalah nonprobability sampling dengan metode purposive sampling, penyebaran skala dilakukan dengan memberikan kuisioner secara offline kepada pasien. Diperoleh subyek sebanyak 145 pasien yang mayoritas berusia $>40$ tahun, mayoritas sudah menikah, dan mayoritas perempuan.

\section{Pengukuran}

Perceived social support diukur dengan menggunakan skala Multidimentional Scale of Perceived Social Support yang disusun oleh Zimet, et al (1988). Skala terdiri dari 12 aitem yang mengukur 3 sumber perceived social support yaitu keluarga, teman, dan significant others. . Seluruh aitem dinilai menggunakan 4 poin skala Likert, mulai dari 1 "Sangat tidak setuju", 2 "Tidak Setuju", 3 "Setuju", dan 4 "Sangat setuju". Psychological distress diukur dengan menggunakan skala Hopkins Symptom Checklist - 25 (HSCL 25). Skala ini terdiri dari 25 aitem, dimana 10 aitem untuk mengukur kecemasan dan 15 aitem lainnya untuk mengukur depresi. Keseluruhan aitem akan dinilai menggunakan 4 poin skala Likert, mulai dari 1 "Sama sekali tidak mengganggu", 2 "Sedikit mengganggu", 3 "Cukup mengganggu", dan 4 "Sangat mengganggu". Skala MSPSS memiliki koefisien Cronbach Alpha sebesar 0.853 , sedangkan HSCL 25 memiliki reliabilitas sebesar 0.939 , kedua skala tersebut dapat dikatakan memiliki reliabilitas yang sangat tinggi.

\section{Analisis data}

Data yang diperoleh kemudian dianalisis menggunakan analisis korelasi Pearson product moment dengan software pengolah data IBM SPSS statistic versi 25.0 for windows.

\section{Hasil}

Deskripsi data ini merupakan gambarangambaran data yang diperoleh dari penelitian yang berupa skor maksimum, skor minimum, 
nilai rata-rata dan standar deviasi dari masing masing variabel. Peneliti mendapatkan skor hipotetik dari penghitungan secara manual

Tabel 1. Deskripsi Data Variabel Penelitian kemudian skor empirik dari perhitungan dengan aplikasi SPSS 25.0 for windows.

\begin{tabular}{llcc}
\hline Variabel & Statistik & Hipotetik & Empirik \\
\hline Perceived Social Support & Nilai Minimum & 12 & 25 \\
& Nilai Maksimum & 48 & 48 \\
& Mean & 30 & 38,05 \\
& Standar Deviasi & 6 & 5,25 \\
Psychological Distress & Nilai Minimum & 25 & 25 \\
& Nilai Maksimum & 100 & 97 \\
& Mean & 62,5 & 43,25 \\
& Standar Deviasi & 12,5 & 15,11 \\
\hline
\end{tabular}

Tabel diatas menunjukkan skor hipotetik dan empirik pada skala yang digunakan dalam penelitian. Peneliti akan mengetahui kategori skor yang dimiliki oleh subjek melalui skor hipotetik, kategori tersebut mengacu pada mean dan nilai standar deviasi pada

\section{Tabel 2. Kategorisasi Variabel Berdasarkan Skor Hipotetik}

\begin{tabular}{lclcc}
\hline \multicolumn{1}{c}{ Variabel } & Daerah Keputusan & Kategori & Jumlah Subjek & Persentase \\
\hline Perceived & $X<24$ & Rendah & 0 & $0 \%$ \\
Social & $24 \leq X<36$ & Sedang & 43 & $29,7 \%$ \\
Support & $36 \leq X$ & Tinggi & 102 & $70,3 \%$ \\
Total & & & 145 & $100 \%$ \\
& & & 104 & $71,7 \%$ \\
Psychological & $X<50$ & Rendah & 36 & $24,8 \%$ \\
Distress & $50 \leq X<75$ & Sedang & 5 & $3,5 \%$ \\
Total & $75 \leq X$ & Tinggi & 145 & $100 \%$ \\
\hline
\end{tabular}

Berdasarkan tabel diatas menunjukkan bahwa pada variabel perceived social support tidak ada subjek yang masuk kategori rendah, sebanyak 102 subjek berada pada kategori tinggi dengan presentase sebesar $70,3 \%$ dan 43 subjek berada pada kategori sedang (29,7\%). Pada variabel psychological distress sebanyak 5 orang berada pada kategori tinggi $(3,5 \%), \quad 36$ subjek berada pada kategori skor hipotetik (Azwar, 2014). Selanjutnya subjek dalam penelitian ini dikategorisasikan berdasarkan tiga kategori berdasarkan norma rendah, sedang, dan tinggi yang sudah didasarkan pada hasil skor masing-masing variabel.

\section{Tabel 3. Hasil Uji Hipotesis}

\begin{tabular}{ccc}
\hline Sub skala & Sig. & Correlation \\
\hline Family & 0,571 & $-0,047$ \\
Friends & 0,654 & $-0,038$ \\
Significant Others & 0,969 & $-0,003$ \\
\hline
\end{tabular}


Hasil dari uji hipotesis menunjukkan bahwa tidak terdapat hubungan yang signifikan antara variabel perceived social support dengan variabel psychological distress pada pasien kanker sehingga hipotesis alternatif $(\mathrm{Ha})$ ditolak. Hasil pada tabel diatas menunjukkan bahwa nilai signifikansi variabel psychological distress dengan masing-masing sub skala perceived social support yang meliputi family, friends, dan significant others adalah 0,571, 0,654, $0,969(>0,05)$, sehingga kedua variabel tersebut tidak menunjukkan korelasi negatif yang signifikan. Hal ini berarti bahwa tinggi rendahnya tingkat perceived social support yang dimiliki pasien tidak berhubungan dengan psychological distress yang dialami.

\section{Pembahasan}

Hasil penelitian ini menunjukkan bahwa tidak terdapat korelasi antara perceived social support dengan psychological distress pada penderita penyakit kanker. Hasil ini tidak selaras dengan beberapa penelitian sebelumnya yang menunjukkan bahwa perceived social support berhubungan negatif dengan psychological distress pada pasien (Nevo, et al., 2018). Faktor intrapersonal, seperti sifat-sifat kepribadian dan pengaruh situasional, seperti kognitif dan fisiologis merupakan faktor lain yang dapat mempengaruhi tingkat psychological distress (Matthews, 2000). Adanya faktor lain tersebut, yang tidak dipertimbangkan dalam penelitian ini, dapat menjadi penyebab mengapa hipotesis alternatif $(\mathrm{Ha})$ dalam penelitian ini ditolak.

Hasil penelitian ini hampir sama dengan hasil penelitian Nurjanah dan Fourianalistyawati (2013) dimana tidak ditemukan hubungan yang signifikan antara dukungan sosial dengan kecemasan pada pasien kanker payudara, adanya faktor sosial ekonomi dan kondisi pasien yang sudah lama menjalani perawatan menyebabkan pasien sudah berada pada tahap acceptence sehingga dukungan sosial sudah tidak terlalu dirasakan dan pasien lebih fokus pada masalah keuangan agar tetap dapat menjalani pengobatan (Nurjanah \& Fourianalistyawati, 2013).

Tidak signifikannya hubungan antara perceived social support dan psychological distress dalam penelitian ini juga didukung oleh hasil penelitian Mertz (2012) yang menunjukkan bahwa ketersediaan dukungan sosial dari pasangan atau seseorang di luar keluarga tidak memengaruhi tingkat psychological distress pada pasien kanker di Denmark, penelitian tersebut menunjukkan bahwa pasien lebih muda cenderung memiliki tingkat psychological distress yang lebih tinggi daripada pasien yang lebih tua (Martz, 2012). Penderita kanker berusia lebih muda $(<40)$ dilaporkan mengalami distress emosional dan fisik yang lebih tinggi dibandingkan dengan penderita kanker yang berusia lebih tua, hal ini mungkin dikarenakan dampak dari kanker pada pasien yang lebih muda umumnya tidak terduga dan mereka mungkin merasa sulit untuk menerima penyakit dan pengobatannya (Almigbal, et al., 2019). Subjek yang didapatkan dalam penelitian kami mayoritas adalah subjek berusia $>40$ tahun yang mungkin lebih resilien dan menyebabkan mereka memiliki psychological distress yang rendah. Rata-rata skor psychological distress pada pasien usia $<40$ tahun juga lebih tinggi dibanding usia $>40$ tahun.

Mayoritas subjek dalam penelitian ini adalah pasien yang sudah menikah $(75,9 \%)$, dan rata-rata skor psychological distress subjek yang menikah lebih rendah dibandingkan dengan subjek yang lajang. Hal ini sesuai dengan hasil penelitian Srivasta (2016) yang menunjukkan bahwa pasien dengan status lajang memiliki depresi dan kecemasan yang lebih tinggi. Penelitian Kamen (2015) juga menunjukkan hal yang sama dimana pasien yang tidak/belum menikah memiliki skor psychological distress yang lebih tinggi dibandingkan pasien yang menikah (Kamen, 2015).

Berdasarkan perhitungan secara hipotetik data yang didapat dari variabel perceived social support menunjukkan bahwa subjek yang memiliki skor tinggi lebih banyak yaitu 102 orang dan tidak ada subjek 
yang memiliki skor rendah, sehingga dapat dikatakan bahwa rata-rata subjek memiliki perceived social support yang tinggi dimana rata-rata skor tertinggi adalah pada dimensi keluarga, kemudian significant others, lalu teman. Hal ini sesuai dengan penelitian Matzka (2016) yang menunjukkan hasil bahwa dalam sampelnya nilai perceived social support mendekati skor tertinggi yang dapat dicapai yang merepresentasikan bahwa pasien menilai dukungan sosial sosial mereka sangat memadai. Namun dukungan sosial hanya signifikan terkait dengan tingkat aktivitas fisik yang lebih baik pada pasien kanker tetapi tidak pada psychological distressnya. Jalur moderator dari social support juga tidak menunjukkan hubungan yang signifikan dengan psychological distress atau tingkat aktivitas fisik, dengan demikian Matzka, et al (2016) dalam penelitiannya tidak dapat mengkonfirmasi keterkaitan dari social support pada psychological distress atau efek moderasi dari social support terhadap tingkat aktivitas fisik dan psychological distress dalam sampelnya (Matzka, et al., 2016).

Hal tersebut juga senada dengan penelitian Dewayani, Sukarlan, \& Turnip (2011) yang meneliti tentang perceived peer social support dengan psychoogical distress pada mahasiswa UI, hasil menunjukkan bahwa tidak ada perbedaan signifikan psychological distress antara mahasiswa yang memiliki perceived peer social support dengan yang tidak, hal ini disebabkan karna psychological distress sendiri memiliki dua faktor utama yang mempengaruhi yaitu faktor intrapersonal dan situasional. Dukungan sosial adalah salah satu dari faktor situasional, dan tidak signifikannya hasil penelitian tersebut membuat peneliti menyimpulkan bahwa terdapat faktor lain selain dukungan sosial yang memiliki pengaruh yang lebih tinggi terhadap tingkat psychological distress mahasiswa UI (Dewayani, Sukarlan, \& Turnip , 2011).

Beberapafaktoryang dapatmempengaruhi tingkat psychological distress pada pasien kanker namun tidak diukur dalam penelitian ini antaralain religiusitas/spiritualitas, resiliensi, kepribadian, dan pengetahuan tentang penyakit. Penelitian dari Biegler (2012) menunjukkan bahwa religiusitas/spiritualitas memoderasi pengaruh dari dukungan sosial terhadap distress pada pasien kanker, seperti hubungan negatif antara dukungan sosial dan persepsi stres serta gangguan mood dimana variabel tersebut hanya signifikan apabila individu memiliki skor religiustitas/ spiritualitas yang tinggi. Religiusitas dapat melengkapi dukungan sosial yang memfasilitasi adaptasi psikologis terhadap penyakit dan membantu pasien kanker untuk mengatasi penyakit mereka, bertambahnya keyakinan religius memberikan dampak positif dan meningkatkan resiliensi, dimana relisiensi berdampak pada kesehatan mental (Fradelos, 2018). Ketika seseorang resilien secara psikologis, resiliensi tersebut dapat memoderasi dan memiliki hubungan positif dengan perceived social support dimana kedua variabel tersebut berhubungan negatif dengan psychological distress (Nigah, Ajmal, \& Abid, 2019).

Penelitian pada pasien kanker prostat oleh Perry, Michael, Jonathan, Sartor, dan Duberstein (2018) menunjukkan bahwa kepribadian juga dapat mempengaruhi emosional distress yang meliputi kecemasan, depresi, dan ide bunuh diri pada pasien kanker. Hasil penelitian tersebut menunjukkan bahwa emosional distress lebih umum terjadi pada pasien dengan kepribadian yang cenderung rapuh seperti neurotic dan introvert. Individu neurotik dan introvert mungkin kurang adaptif dan kurang memiliki strategi regulasi emosional dalam menanggapi transisi kehidupan yang berpotensi menimbulkan distress. Misalnya, individu neurotik dapat menilai diagnosis kanker lebih mengancam atau parah, sehingga mengalami peningkatan tekanan emosional. Seorang introvert mungkin lebih kecil kemungkinannya untuk mencari dukungan sosial daripada seorang ekstrovert, sehingga kurang siap untuk menghadapi tekanan hidup dengan penyakit serius (Perry, et al., 2018).

Pengetahuan/informasi tentang penyakit kanker atau perawatan kanker yang didapatkan oleh pasien juga menjadi salah satu faktor yang dapat mempengaruhi 
psychological distress pasien kanker. Hasil penelitian Ojewole tahun 2018 menyatakan bahwa jika kebutuhan informasi tentang penyakit kanker atau perawatan kanker tidak terpenuhi maka akan berdampak pada tingginya psychological distress pasien. Pasien yang telah diedukasi mengenai perawatan kanker dan pemulihannya memiliki prevalensi dan resiko depresi yang lebih rendah Tian (2015).

Terdapat beberapa keterbatasan dalam penelitian ini antara lain peneliti tidak meneliti lebih jauh mengenai stadium kanker yang dialami pasien dan tidak mempertimbangkan resiliensi atau religiusitas pasien dimana hal ini dapat mempengaruhi psychological distress pasien. Perceived social support pasien juga hanya dilihat berdasarkan sumbernya saja tidak dilihat berdasarkan jenis-jenis atau bentuk-bentuk dukungan sosial yang diterima oleh pasien.

\section{Kesimpulan}

Berdasarkan hasil uji hipotesis dan pembahasan yang telah dilakukan, dapat disimpulkan bahwa tidak terdapat hubungan yang signifikan antara perceived social support dengan psychological distress pada penderita penyakit kanker. Penelitian selanjutnya diharapkan dapat memasukkan variabel religiusitas, resiliensi, atau kepribadian sebagai variabel moderasi antara perceived social support dan psychological distress. Penelitian selanjutnya juga diharapkan dapat mengukur social support berdasarkan jenisjenis atau bentuk-bentuk dukungan sosial yang didapatkan pasien.

\section{Daftar Pustaka}

Almigbal, T. H., Almutairi, K. M., Fu, J. B., Vinluan, J. M., Alhelih, E., Alonazi, W. B., ... Mubaraki, M. A.(2019). Assessment of psychological distress among cancer patients undergoing radiotherapy in Saudi Arabia. Psychology Research and BehaviorManagement, 12, 691- 700 .
Barrera, M. (1986). Distinctions between social support concepts, measures, and models. American Journal of Community Psychology, 14(4),413-445.

Biegler, K., Cohen, L., Scott, S., Hitzhusen, K., Parker, P., Gilts, C. D., Pisters, L. (2012). The role of religion and spirituality in psychological distress prior to surgery for urologic cancer.Integrative Cancer Therapies, 11(3), 212-220.

Derogatis, L. R., \& Cleary, P. A. (1977). Confirmation of the dimentional structure of the scl 90: a study in construct validation. Jurnal of Clinical Psychology, 33(4),982-989.

Derogatis, L. R., Lipman, R. S., Rickels, K., Unlenhuth, E., \& Covi, L. (1974). The hopskin symptom checlist (HSCL): a self report symptom inventory. Behavioral Science, 19,1-15.

Dewayani, A., Sukarlan, A., \& Turnip , S. (2011). Perceived peer social support dan psychological distress mahasiswa univrsitas indonesia. Makara Sosial Humaniora, 15(2),86-93.

Fradelos, E. C., Latsou, D., Mitsi, D., Tsaras, ., Lekka, D., Lavdaniti, M., ... Papathanasiou, I.V. (2018). Assessment of the relation between religiosity, mental health, and psychological resilience in breast cancer patients. Contemporary Oncology, 22 (3),172-177 DOI: https://doi.org/10.5114/ wo.2018.78947.

Gunduz, N., Unsen, A., \& Atar, E. A. (2018). The impact of perceived social support on anxiety, depression and severity of pain and burnout among turkish females with fibromyalgia. Turkish League Against Rheumatism, 186-195.

Haber, M. G., Cohen, J. L., \& Lucas, T. (2007). The relationship between selfreportedreceived and perceived social support: a meta-analytic review. American Journal of Community Psychology, 39,133-144.

Hamer, M., Chida, Y., \& Molloy, G. J. (2009). Psychological distress and cancer mortality. Journal of Psychosomatic Research, 66, 255-258.

Hamzah, I. F., Dewi, E. K., \& Suparno. (2014). Makna sakit pada penderita penyakit jantung koroner. Jurnal Psikologi 
Undip, 13(1),1-10.

Kamen, C., M. Mustian, K., Heckler, C., C. Janelsins, M., Peppone, L., Mohile, S., . . . Morrow, G. (2015). The association between partner support and psychological distress among prostate cancer survivors in a nationwide study. Journal of Cancer Survivorship, 9(3),492499.

Kemenkes. (2019). Hari kanker sedunia 2019. Retrieved from Depkes: 31 Januari 2019 http://www.depkes.go.id/ article/view/19020100003/hari-kankersedunia-2019.html

Khawar, M., Aslam, N., \& Aamir, S. (2013). Perceived social support and death anxiety among patients with chronic diseases. Pakistan Journal of Medical Research, 52(3),75-79.

Kim, G. M., Kim, S. J., Song, S. K., \& Kim, H. R. (2017). Prevalence and prognosticimplications of psychological distress in patients with gastric cancer. BMC Cancer, 283.

Kirana, L. A. (2016). Dukungan sosial dan resiliensi pada pasien kanker payudara (studi kasus pada pasien kanker payudara yang sedang menjalani kemo-terapi). JurnalPsikoborneo, 4 (4),829- 837.

Lopez, M. L., \& Cooper, L. (2011). Social support measures review. National Center for Latino Child \& Family Research, 7-16.

Lourel, M., Hartmann , A., Closon, C., \& Moud, F. (2013). Social support and health: an overview of selected theoretical models for adaptation. Science Sociales, Isbn:978 1626186484.

Madani, H., Pourmemari, M., Moghimi, M., \& Rasvand, F. (2018). Hopelessness, perceived social support and their relationship in Iranian patients with cancer. Journal of Asian O n chology Nursing Society, 5(3), 314-319.

Martin, C. M. (2007). Chronic disease and illness care. Canadian family physician, 53, 20862091.

Matthews, G. (2000). Distress. Fink (ed) in Encyclopedia of stress Volume 1 (A-D): New York: Academic press.

Matzka, M., Mayer, H., Köck-Hódi, S., Moses-Passini, C., Dubey, C., Jahn, P., \& Schneeweiss, S. (2016).Relationship between resilience, psychological distress and physical activity in cancer patients: a cross-sectional observation study. Plos One, 11,1-13. DOI:10.1371/ journal.pone.0154496.

Mertz, B. G., Bistrup, P.E., Johansen, C., Dalton , S. O., Deltour , I., Kehlet, H., \& Kroman N.(2012). Psychological distress among women with newly diagnosed breast cancer. European Journal of Oncology Nursing, 16(4), 439-443. doi:10.1016/j.ejon.2011.10.001.

Mirowsky, J., \& Ross, C. E. (2003). Social causes of psychological distress. New York: Aldine De Gruyer.

Nevo, V. S., Sarid, O., Friger, M., Schwartz, D., Sergienko, R., Pereg, A., . . Odes, S. (2018). Effect of social support on psychological distress and disease activity in inflammatory bowel disease patients. Journal of Inflammatory Bowel Disease, 00:1 11.doi/10.1093/ibd/izy041/ 4980713.

Ng, C. G., Mohamed, S., See, M. H., Harun, F., Dahlui, M., Sulaiman, A. H., . . Taib, N. A. (2015). Anxiety, depression, perceived social support and quality of life in Malaysian breast cancer $\mathrm{p}$ a $\mathrm{t}$ i e $\mathrm{n} \mathrm{t} \mathrm{s}$ : a 1-year prospective study. Health and Quality of Life Outcomes, 2-9.

Nigah, Z., Ajmal, A., \& Abid, S. (2019). Resilience, perceived social support and psychological stress in diagnosis of cancer. Isra Medical Journal, 11(1), 3640.

Nurjanah, Z. S., \& Fourianalistyawati, E. (2013). Hubungan antara dukungan sosial dengan kecemasan pada pasien kanker payudara. Jurnal Psikologi Yarsi, 2-18.

Ojewole, F. O., Madu, A., \& Nwozichi, C. (2018). Association between psychological distress and unmet information needs among female cancer patients in two selected teaching hospitals in SouthWest Nigeria. Chrismed Journal of Health and Research, 5 (1), 1117 DOI: 10.4103/ cjhr.cjhr_62_17.

Perry, L. M., Michael, H., Jonathan, S., Sartor, O., \& Duberstein, P. (2018). Understanding the distressed prostate cancer patient: role of personality. 
Psychooncology, 27(3), $810 \quad 816$. doi:10.1002/pon.4579.

Prastiwi, T. F. (2012). Kualitas hidup penderita kanker. Developmental and Clinical Psychology, 1(1), 21-27.

Riskesdas. (2018). Hasil utama riskesdas 2018. Kemenkes Badan Penelitian dan Pengembangan Kesehatan.

Roohafza, H. R., Afshar, H., Keshteli, A. H., \& Narg. (2014). What's the role of perceived social support and coping styles in depression and anxiety? Journal of Research in Medical $S$ ci e n c e s, 19,944-9.

Sohail, M., Yasin, M., \& Ahmad, S. (2017). A phenomenological account of social sources, coping effects and relational role of social support in nursing among chronic patients with hepatitis. Journal of Research in Nursing, 23(1), 23-39.

Srivastava, V., Ansari, M. A., Kumar, A., Gauta, A., Meena, R. K., Sevach, P., \& Singh, O. P. (2016). Study of anxiety and depression among breast cancer patients from north india. Clinical Psychiatry, 2, 1-4, doi: 10.21767/2471-9854.100017.

Tian, J., Jia, L., \& Cheng, Z. (2015). Relationships between patient knowledge and the severity of side effects, daily nutrient intake, psychological status, and performance status in lung cancer patients. Current Oncology, 22(4),254258.

Turnip, S. S., \& Hauff, E. (2007). Household roles, poverty and psychological distress in internally displaced persons affected by violent conflicts in Indonesia. Soc Psychiatry Psychiatr Epidemiol , 42,9971004.

Verhaak, P. F., Heijmans, M. J., Peters, L., \& Rijk, M. (2005). Social science \& medicine. Chronic Disease and Mental Disorder, 60, 789-797, doi:10.1016/j. socscimed.2004.06.012.

Vodermaier, A., \& Marshall, C. (2011). Disease stage predicts post-diagnosis anxiety and depression only in some types of cancer. British Journal of Cancer, 105, 1814 1817.

WHO. (2018). World Health Organization.

Retrieved from Cancer: 2018, 12 September 2018 https://www.who.int/ newsroom/fact-sheets/detail/cancer

Widakdo, G., \& Besral. (2013). Effects of chronic illness to the mental emotional disorders. Jurnal Kesehatan Masyarakat Nasional, 7(7),309-916.

Widiyono, S. (2017). Tingkat depresi pada pasien kanker di rsup dr. sardjito, yogyakarta, dan rsud prof. dr. margono soekarjo, purwokerto: pilot study. Indonesian Journal of Cancer, 11(4), 171-177.

Winokur, A., Winokur, D. F., Rickels, K., \& Cox, D. S. (1984). Symptoms of emotional distress in a family planning service: stability over a four-week period. Journal of Psychiatric, 95-399.

Yilmas, M. S., Piyal, B., \& Akdul, R. (2017). Social support and quality of life in a group of cancer patients. Turkish Journal of Medical Sciences, 47, 732-737.

Yoo, H., Shin, D. W., Jeong, A., Kim, S. Y., Yang, H. k., Kim, J. S., . . Park, J. H. (2017). Perceived social support and its impact on depression and healthrelated quality of life: a comparison between cancer patients and general population. Japanese Journal of Clinical Oncology, 47(8),728-734.

Zimet, G. D., \& Mitchell, J. C. (2000). Psychometric properties of the multidimensional scale of perceived social support in urban adolesence. American Journal of CommunityPsychology, 28(3), 391-400.

Zimet, G. D., Dahlem, N. W., Zimet, S. G., \& Farl, G. K. (1988). The multidimensional scale of perceived social. Journal of Personality Assesment, 52(1), 30-41, DOI: 10.1207/s15327752jpa5201_2.

Zimet, G. D., Powel, S. S., Farley, G. K., Werkman, S., \& Berkoff, K. A. (1990). Psychometric characteristics of the multi-dimentional scale of perceived social support. Journal of Personality Assesment, 55(3-4), 610-617, DOI:10.10 80/00223891.1990.9674095. 